\title{
Urgensi Akal Menurut Al Qur'an Dan Implikasinya Dalam Mencapai Tujuan Pendidikan Islam
}

\author{
M. Arif Setiawan, ${ }^{1}$ Melvien Zainul Asyiqien ${ }^{2}$ \\ 1 Prodi PAI Pascasarjana IAIT Kediri, Institut Agama Islam Tribakti Kediri \\ ${ }^{1}$ arief.dw.98@gmail.com,2melvienzainul20@gmail.com
}

\begin{abstract}
Reason and the Qur'an know each other and are recognized in Islamic science. In this context, many researchers are interested in examining the relationship of reason and the Qur'an. According to Dr. Muhammad Nahadi, discussion of reason, the Qur'an in the context of knowledge is the concept of developing knowledge. In line with this development, the development of Islamic education in the context of the study of reason and the Qur'an is urgently needed, especially as a means of answering the challenges of education with global challenges. This type of research is literature research, which is a form of scientific reasoning argumentation appearance that describes the results of literature studies and the results of the author's thought about a problem / topic of study. And data collection techniques using library research techniques, or library research, with data processing techniques. The data analysis process begins by gathering all data about the reason and objectives of Islamic education in order to find out the implications of reason in achieving the objectives of Islamic education. The results of this study indicate that, first, reason is the power of thought that when used can lead a person to understand and comprehend the problem he is thinking about. Second, reason serves as a tool for thinking, pondering and living also to develop ideas, concepts and bright ideas, very closely related to education. So that reason in its implications for the objectives of Islamic education is crucial to the success or failure of a person in achieving the goals of Islamic education.
\end{abstract}

Keywords: Intelligence, Implications, Purpose of Islamic Education

\begin{abstract}
Abstrak
Akal dan Al Qur 'an saling bertauatan dan diakuai dalam ilmu keIslaman. Dalam konteks ini, banyak peneliti tertarik mengkaji hubungan akal dan $\mathrm{Al}$ Qur' an. Menurut Dr. Muhammad Nahadi, pembahasan akal, Al Qur an dalam konteks pengetahuan merupakan konsep pengembangan pengetahuan. Sejalan dengan perkembangan itu, pengembangan pendidikan Islam dalam konteks kajian akal dan $\mathrm{Al}$ Qur an sangat dibutuhkan, terlebih sebagai sarana menjawab tantangan pendidikan dengan tantangan global. Jenis penelitian ini adalah penelitian kepustakaan (literery research), yaitu bentuk penampilan argumentasi penalaran keilmuan yang memaparkan hasil kajian pustaka dan hasil olah pikir penulis mengenai suatu masalah/topik
\end{abstract}


kajian. Dan teknik pengumpulan data menggunakan teknik library research, atau riset kepustakaan, dengan teknik pengolahan data. Proses analisis data diawali dengan mengumpulkan seluruh data tentang akal dan tujuan pendidikan Islam guna mengetahui implikasi akal dalam mencapai tujuan pendidikan Islam. Hasil penelitian ini menunjukkan bahwa, pertama, akal adalah daya pikir yang bila digunakan dapat mengantar seseorang untuk mengerti dan memahami persoalan yang dipikirkannya. Kedua, akal berfungsi sebagai alat untuk berfikir, merenung serta menghayati juga untuk mengembangkan gagasan, konsep dan ide-ide cemerlang, sangat erat kaitannya dengan pendidikan. Sehingga akal dalam implikasinya terhadap tujuan pendidikan Islam sangat menentukan berhasil tidaknya seseorang dalam mencapai tujuan pendidikan Islam.

Kata kunci: Akal, Implikasi, Tujuan Pendidikan Islam

\section{Pendahuluan}

Akal merupakan perangkat lunak yang ada pada diri manusia sehingga berbagai kajian teori mulai sejak awal Islam hingga saat ini tidak ada habisnya dan selalu mengalami perkembangan. Dikarenakan sifatnya dalam memahami pengetahuan semakin berkembang di setiap zaman, akal seolah menjadi misteri yang tak terpecahkan. Beragam pendapat pun bermunculan tentang konsep akal. Pendapat tersebut tentu tergantung dari sudut pandang yang ditelaah.

Materi 'aql dalam Al Qur'an terulang sebanyak 49 kali. Kecuali satu, semuanya datang dalam bentuk fi'il mudhari' terutama materi yang bersambung dengan wawu jama'ah, seperti bentuk ta'qilun atau ya'qilun. Kata kerja ta'qilun terulang sebanyak 24 kali dan kata kerja ya'qilun sebanyak 22 kali. Sedangkan kata kerja 'aqala, na'qilu, dan ya'qilu masing-masing terdapat satu kali. Sebagai contoh adalah redaksi af'alaa ta'qilun, yang paling mencolok dalam redaksi tersebut adalah penggunaan bentuk istifham inkari (pertanyaan negatif).

Perbuatan manusia yang bertentangan dengan pengetahuannya dan bertentangan dengan perintah yang ia berikan kepada orang lain, tidak akan timbul kecuali dari orang yang tidak lurus pemikiran yang tidak matang. Manusia seperti ini boleh jadi memiliki gangguan akal. Dalam perspektif lain, ilmu psikologi misalnya, ada kecenderungan akan untuk menyederhanakan pemehaman konteks. $^{1}$ Hal ini seringkali menjadi manusia dianggap tidak penuh kemampuan akalnya. Istilah lain gangguan psikis.

Akal bukan hanya daya pikir, tetapi gabungan dari sekian daya dalam diri manusia yang menghalanginya

1 Yusuf Qardhawi "Al-Qur'an Berbicara tentang Akal dan Ilmu Pengetahuan," (Jakarta: Gema Insani), h, 19-20 
terjerumus ke dalam dosa dan kesalahan. Karena itulah maka ia dinamai oleh Al Qur'an dengan 'aql (akal) yang secara harfiah berarti tali, yakni yang mengikat hawa nafsu manusia dan menghalanginya terjerumus kedalam dosa, pelanggaran dan kesalahan. Hal ini dapat kita lihat dalam Q.S. Ar-Rum ayat 24 berikut:

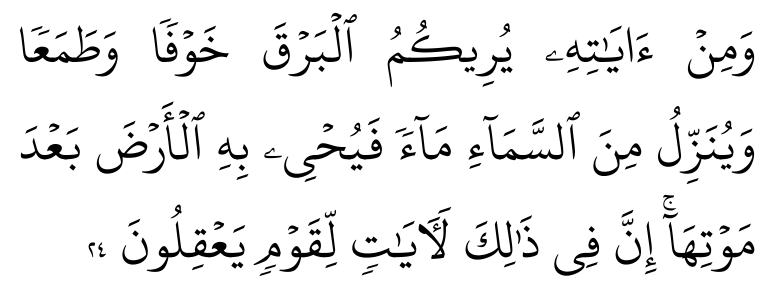

Terjemahnya: "Dan di antara tanda-tanda kekuasaan-Nya, Dia memperlihatkan kepadamu kilat untuk (menimbulkan) ketakutan dan harapan, dan Dia menurunkan hujan dari langit, lalu menghidupkan bumi dengan air itu sesudah matinya. Sesungguhnya pada yang demikian itu benar-benar terdapat tandatanda bagi kaum yang mempergunakan akalnya."

Menurut Nurcholish Madjid pentingnya peran akal dalam kehidupan manusia dapat dilihat dalam sejarah Allah mengajarkan nama-nama (al-asma'a kullaha). Sebutan akal sering digunakan oleh Nurcholish Madjid adalah akal budi. Ia menambahkan dengan akal budi, manusia memiliki dalam dirinya kemampuan naluriah untuk mencapai hikmah kearifan yang lebih tinggi dari sekadar ilmu pengetahuan. Adam sebagai manusia sempurna dalam alam primordial mampu menerima pengajaran dari Tuhan. ${ }^{2}$
Selanjutnya akal sangat berperan dalam menyusun tujuan Pendidikan Islam. Akal bekerja merenungi dan memikirkan serta mencari jawabanjawaban berdasarkan sumber ajaran Islam untuk merumuskan tujuan Pendidikan Islam. Secara umum, tujuan Pendidikan Islam adalah perwujudan nilai-nilai Islami untuk mencapai hasil (produk) yang berkepribadian Islam yang beriman dan bertakwa kepada Tuhan Yang Maha Esa, berahklak mulia, sehat, berilmu, cakap, kreatif, mandiri, dan menjadi warga negara yang demokratis serta bertanggung jawab.

Sedangkan secara spesifik Pendidikan Islam sebagai salah satu proses pengetahuan juga menggunakan daya pikir akal untuk menyalurkan dan memahami suatu dimensi ilmu yang bersumber dari Al Qur an dan al Hadist agar manusia mampu mengenali dan bertawakal kepada penciptanya. Dalam konteks ini, akal difungsikan memahami kodratnya sebagai instrument memahami ilmu-ilmu yang diturunkan oleh Allah SWT.

Uraian di atas menunjukkan bahwa akal mempunyai posisi yang begitu penting dalam kehidupan manusia, sehingga dengan akal manusia mampu menangkap realitas, dan memahami ilmu-ilmu yang diturunkan oleh Allah SWT. Sebagai penghargaan tentang keberadaan akal, manusi pun dijadikan Allah SWT sebagai kholifah di muka bumi. 


\section{Metode Penelitian}

Metode penelitian yang digunakan dalam penelitian ini adalah penelitian kepustakaan atau library research, yakni penelitian yang dilakukan melalui mengumpulkan data atau karya tulis ilmiah yang bertujuan dengan obyek penelitian atau pengumpulan data yang bersifat kepustakaan, atau telaah yang dilaksanakan untukmemecahkan suatu masalah yang pada dasarnya tertumpu pada penelaahankritis dan mendalam terhadap bahan-bahan pustaka yang relevan. ${ }^{3}$

Secara tegas, metode penelitian kajian pustaka atau studi kepustakaan yaitu berisi teori teori yang relevan dengan masalah-masalah penelitian. Adapun masalah pada penelitian ini adalah untuk mengetahui urgensi Akal Menurut Al Qur an dan implikasinya dalam mencapai tujuan pendidikan Islam. ${ }^{4}$

Penelitian ini dilakukan pengkajian mengenai konsep dan teori yang igunakan berdasarkan literatur yang tersedia, terutama dari kitab-kitab tafsir al Quran yang didukung oleh artikelartikel yang dipublikasikan dalam berbagai jurnal ilmiah. Kajian pustaka berfungsi untuk membangun konsep atau teori yang menjadi dasar studi dalam penelitian.

\section{Pembahasan}

\section{Kajian Akal Menurut Al-Quran}

Al Qur'an berulang-ulang menggerakkan dan mendorong perhatian manusia dengan bermacam cara, supaya manusia mempergunakan akal. Ada secara tegas, perintah mempergunakan akal dan ada pula berupa pertanyaan, mengapa seseorang harus menggunakan akal. Di sisi lain diterangkan pula, bahwa segala benda di langit dan di bumi menjadi bukti kebenaran tentang kekuasaan, kemurahan dan kebijaksanaan Tuhan. Hal ini hanya mampu dipahami oleh orang yang menggunakan akal.

Meskipun demikian, tidak bisa dipungkiri timbulnya perpecahan antara satu golongan sesamanya, disebutkan karena akal. Dalam kehidupannya, manusia sering menghadapi berbagai masalah, dimana masalah tersebut harus dipecahkan. Tanpa adanya pemikiran yang sehat dan jernih, manusia tidak akan menyelesaikan permasalahan tersebut. Akal mempunyai kemampuan untuk menyelesaikan segala permasalahan manusia. Begitu pentingnya akal, Al Quran memberikan penghargaan setinggi-tingginya. Seperti yang disebutkan dalam Al Qur'an Qs Az Zumar ayat 9 yang menyebutkan: "(Apakah kamu hai orang musyrik yang lebih beruntung) ataukah orang yang beribadat di waktu-waktu malam dengan sujud dan berdiri, sedang ia takut kepada

${ }^{4}$ V.Wiratna Sujarweni,Metodeologi Penelitian (Yogyakarta : Pustaka Baru Perss, 2014), h.57 
(azab) akhirat dan mengharapkan rahmat Tuhannya? Katakanlah: "Adakah sama orang-orang yang mengetahui dengan orang-orang yang tidak mengetahui?" Sesungguhnya orang yang berakallah yang dapat menerima pelajaran."

Selaian Al Qur an, Al Hadist juga banyak mengagungkan keberadaan akal.bRasulullah SAW. bersabda,"Pena (catatan pahala dan dosa) diangkat (dibebaskan) dari tiga golongan, di antaranya orang yang gila sampai ia kembali sadar (berakal)." ( H.R. Abu Daud dari Ali, Sunan Abu Daud, Kitab al-Hudud, vol.II, hal.339. Daar el-Fikr).

Dalam bukunya logika agama Quraish Shihab berpendapat bahwa akal bagaikan mata dan wahyu adalah sinarnya. Mata tidak berfungsi tanpa sinar, dan sinar pun tidak berfungsi menampakkan sesuatu tanpa mata. ${ }^{5} \mathrm{Hal}$ ini menunjukkan bahwa fungsi akal sesungguhnya adalah penerjemah, dalam artian berfikir, merenungkan, mencari tahu, juga memahami realitas yang ada di sekitarnya. Dalam konteks Pendidikan Agama Islam, akal juga mempunyai peran yang sangat penting.

Pemahaman terhadap potensi berpikir yang dimiliki akal sebagaimana yang telah dipaparkan di atas memiliki hubungan yang amat erat dengan pendidikan. Hubungan tersebut antara lain terlihat dalam merumuskan tujuan pendidikan. Benyamin Bloom, Cs, dalam bukunya Taxonomy of Educational Objective (1956) yang dikutip oleh Nasution, membagi tujuan-tujuan pendidikan dalam tiga ranah (domain), yaitu ranah kognitif, afektif dan psikomotorik. Tiap-tiap ranah dapat dirinci lagi dalam tujuan-tujuan yang lebih spesifik yang hierarkis.

Ranah kognitif dan afektif tersebut sangat erat kaitannya dengan fungsi kerja dari akal. Dalam ranah kognitif terkandung fungsi mengetahui, memahami, menerapkan, menganalisis, mensintesis dan mengevaluasi. Fungsifungsi ini erat kaitannya dengan fungsi akal pada aspek berpikir (tafakkur), sedangkan dalam ranah afektif terkandung fungsi memperhatikan, merespon, menghargai, mengorganisasi nilai, dan mengkarakterisasi. ${ }^{6}$ Fungsifungsi ini erat kaitannya dengan fungsi akal pada aspek mengingat (tazakkur).

Cukup banyak isyarat-isyarat $\mathrm{Al}$ Qur'an tentang penggunaan akal dengan penekanan bahwa penggunaan akal adalah merupakan barometer bagi keberadaan manusia. Manusia dalam berpikiran harus menggunakan pikiran dan qalbu. Daya pikir manusia menjangkau wilayah fisik dari masalahmasalah yang relatif, sedangkan qalbu memiliki ketajaman untuk menangkap makna-makna yang bersifat metafisik dan mutlak. Oleh karenanya dalam hubungan dengan upaya memahami Islam, akal memiliki fungsi sebagai berikut:

1. Akal sebagai alat yang strategis untuk mengungkap dan mengetahui kebenaran yang terkandung dalam Al Qur'an dan Sunnah Rasul,

6 Harun Nasution (1994), “Azas-azas Kurikulum," (Jakarta: Bumi Aksara, 1994),h. 50. 
dimana keduanya adalah sumber utama ajaran Islam.

2. Akal merupakan potensi dan modal yang melekat pada diri manusia untuk mengetahui maksud-maksud yang tercakup dalam pengertian $\mathrm{Al}$ Qur'an dan Sunnah Rasul.

3. Akal juga berfungsi sebagai alat yang dapat menangkap pesan dan semangat Al Qur'an dan Sunnah yang dijadikan acuan dalam mengatasi dan memecahkan persoalan umat manusia dalam bentuk ijtihad.

4. Akal juga berfungsi untuk menjabarkan pesan-pesan al-Quran dan Sunnah dalam kaitannya dengan fungsi manusia sebagai khalifah Allah, untuk mengelola dan memakmurkan bumi seisinya.

Namun demikian, bagaimana pun hasil akhir pencapaian akal tetaplah relatif dan tentatif. Untuk itu, diperlukan adanya koreksi, perubahan dan penyempurnaan terus-menerus. Oleh karena itu taklid buta tidak dianjurkan dalam ajaran Islam. ${ }^{7}$

\section{Hakikat dan Kedudukan Akal}

Pembahasan tentang akal selalu tidak pernah selesai, selain keunikannya, akal juga sangat rumit untuk dijelaskan, maka dari itulah pembahasan terkait dengan akal selalu berkembang dari waktu ke waktu. Berbagai pendapat pun bermunculan ada yang mengatakan bahwa akal itu bagian dari hati dan ada pula yang membedakannya.

Secara istilah, akal digunakan untuk menunjukkan salah satu definisi berikut ini:

a.Kemampuan untuk mengetahui sesuatu.

b.Kemampuan memilah-milah antara kebaikan dan keburukan yang niscaya juga dapat digunakan untuk mengetahui hal-ihwal yang mengakibatkannya dan sarana-sarana yang dapat mencegah terjadinya masing-masing dari keduanya.

c.Kemampuan dan keadaan (halah) dalam jiwa manusia yang mengajak kepada kebaikan dan keuntungan dan menjauhi kejelekan dan kerugian.

d.Kemampuan yang bisa mengatur perkara-perkara kehidupan manusia. Jika ia sejalan dengan budi. Namun, manakala ia menjadi sesuatu yang membangkang dan menentang syariat, maka ia disebut syaithanah.

e. Akal juga dapat dipakai untuk menyebut tingkat kesiapan dan potensialitas jiwa dalam menerima konsep-konsep universal. An-nafs annathiqah (jiwa rasional yang dipergunakan untuk menalar) yang membedakan manusia dari binatang lainnya.

f. Dalam bahasa filsafat, akal merujuk kepada substansi azali yang tidak bersentuhan dengan alam material, baik secara esensial (dzati) maupun aktual (fi'li). 
Jadi akal adalah mahluk yang mengarahkan jiwa dan membuatnya memilih beberapa alternatif serta memberi tahu mana yang baik dan mana yang buruk; mana yang hal mana yang haram. ${ }^{8}$

Nama lain dari akal adalah $l u b b$, ada juga yang mengatakan bahwa kata $l u b b$ adalah sesuatu yang suci dari akal; sehingga dapat dikatakan bahwa setiap $l u b b$ adalah akal tetapi tidak setiap akal adalah $l u b b$. Disamping istilah lubb yang berhubungan dengan akal, terdapat istilah fu'ad dan qalb. Dalam hubungan ini, Abdul Wahid al-Lughawi (wafat 315 H.) berkata: "Qalb adalah sebutan dalam arti fu'ad, tetapi terkadang juga sebagai ungkapan bagi arti akal." 9

Sedangkan dalam al-Qur'an, kata qalb digunakan sebanyak 144 kali. Penggunaan qalb selalu merujuk pada hal-hal yang berkaitan dengan emosi dan akal pada manusia. Ia memiliki arti lebih khusus dari nafs sebagai penggerak naluri atau biologis, yaitu hanya terbatas pada bagian yang disadari. ${ }^{10}$

Menurut Asy-syarqawi dari perenungan terhadap beberapa ayat yang mengandung kata qalb, dapat disebutkan dua fungsi utama dari beberapa fungsi besar yang dimiliki qalb, yaitu: 1) fungsi persepsi, pengetahuan (intuitif), dan ilmu

${ }^{8}$ Ahmad Syauqi Ibrahim Misteri Potensi Ghaib Manusia, Qisthi Press, (Jakarta: Qisthi Press 2012) h. 250

${ }^{9}$ Ahmad Syauqi Ibrahim Misteri Potensi Ghaib Manusia, Qisthi Press, (Jakarta: Qisthi Press 2012) h, . 48

10 Hasan Langgulung, Manusia dan pengetahuan; 2) fungsi keimanan, dan yang terkait dengannya, yaitu emosi, ectasy (kehanyutan dalam kesenangan spiritual), dan potensi kehendak. ${ }^{11}$

Qalb menurut pendangan alGhazali dapat dikonotasikan dalam dua arti yaitu daging berbentuk belahan sanubari yang berada di sisi dada kiri yang berisi darah merah kehitaman dan merupakan sumber ruh kehidupan. Adapun makna yang kedua adalah sifat kelembutan (lathifah), Rabbaniyyah, ruhaniyyah, yang merekat pada kalbu jisim, ia memiliki ketergantungan yang sama seperti tergantungnya jiwa dengan raga, atau seperti tergantungnya sifat dengan hal yang disifatinya. Lathifah sendiri dalam hal ini merupakan hakikat manusia yang memiliki kemampuan memahami, mengetahui, berdialog, yang berpotensi diberi pahala ataupun siksa. ${ }^{12}$

Selain itu al-Ghazali juga mengatakan bahwa qalb sebagai pusat dan sumber ilmu pengetahuan dapat mencetak setiap sesuatu yang dipelajarinya dalam hati dan kemudian diperjelas di dalamnya. Al-Ghazali mengungkapkan bahwa adanya ilmu pengetahuan merupakan esensi dari hati di mana di dalamnya terdapat banyak fakta dan informasi. Sedang sesuatu yang dipelajari adalah bagaikan refleksi dari segala jenis ilmu

Pendidikan, (Jakarta: Pustaka Al Husna Baru, 2014), h, . 234-235

11 Muhammad Abdullah Asy-Syarqawi, Sufisme \& Akal, h, . 72

12 Khafidhi, Peranan Akal dan Qalb Dalam Pendidikan Akhlaq (Studi Pemikiran Al-Ghazali), Semarang: IAIN Walisongo, 2013) h, 123 . 
pengetahuan. Dari pernyataan inilah bias dipahami korelasi antara hati dan ilmu pengetahuan. ${ }^{13}$

\section{Manusia sebagai Makhluk Berakal}

Segala sesuatu yang diciptakan Allah bukanlah dengan percuma saja, tetapi dengan maksud-maksud tertentu yang diinginkan Allah. Demikianlah diantara seluruh makhluk ciptaan Allah, terdapatlah makhluk pilihanNya yaitu manusia. Dan diantara makhluk pilihan itu, maka para Nabi dan Rasul memperoleh tempat tertinggi sebagai manusia pilihan Allah.

Siapakah manusia itu dan bagaimanakah kedudukannya dalam realitas atau jagad raya ini. Demikianlah pertanyaan yang meliputi seluruh pikiran para filsuf, termasuk filsuf Max Scheler. Pertanyaan itu adalah pertanyaan abadi karena pada dasarnya terkandung dalam hati setiap insan sepanjang masa. Bagaimanakah sebenarnya tempat manusia itu dalam jagad raya ini dalam keseluruhan yang ada ini, dalam keseluruhan dunia ini terhadap Tuhannya.

Sesungguhnya manusia merupakan makhluk yang menakjubkan, disamping juga misterius seperti kata Dr. Alexis Carel. Ia akan menjadi jahat jika dihadapannya terbuka jalan kejahatan dan tidak ada pengawasan terhadapnya. Ia juga akan mencapai kedudukan tinggi kalau mampu mengendalikan nafsu serta menun-

13 Muhammad Izzudin Taufiq, Panduan N Lengkap dan Praktis Psikologi Islam, (Jakarta: ₹ Gema Insani Press, 2006) h, . 634 dukkannya. Dalam hal ini pernah ada ungkapan dari Sayyidina Ali karramallahu wajhah: "Apakah kau kira bahwa kau tubuh yang kerdil, padahal padamu terkandung dunia yang sangat besar" 14

Ayat 30-34 Al Baqarah, telah menguraikan tentang ketinggian martabat manusia yang sejak semula diciptakan ke tingkat yang sempurna. Jelas sekali bahwa manusia adalah khalifah Allah SWT, di muka bumi. Manusialah yang ditakdirkan-Nya untuk mensejahterakan, memperbaiki keadaan dan menguasai bumi. Untuk itu Allah menciptakan segala sesuatu yang ada di bumi bagi kepentingan manusia. Kemudian manusia dikaruniai kesanggupan mengenal dan mengetahui segala sesuatu yang ada di dalamnya. ${ }^{15}$ Dan untuk menjalankan tugasnya, manusia dibekali akal sebagai daya pikir, karena mustahil tanpa daya pikir manusia mampu menjalankan tugasnya sebagai khalifah.

Makhluk hidup yang bernama manusia itu, telah dikaruniai hati yang terukir dengan perasaan yang paling lembut dan nurani yang paling tinggi. Selain itu, Allah juga telah mengkaruniai manusia dengan akal pikiran dan pengetahuan sehingga menjadikan ia lebih berpotensi untuk melaksanakan kreatifitas-kreatifitas dalam hidupnya.

Manusia adalah ciptaan Allah SWT, yang diberikan tiga kelebihan

14 Maftuh Ahnan \& Ach. Zacky SyafaFilsafat Manusia, (Surabaya: Terbit Terang, 2001), h, . 93

15 Maftuh Ahnan \& Ach. Zacky Syafa, Filsafat Manusia, , h, . 102 
utama, pertama dari ruh yang bisa membuat manusia hidup di muka bumi, kedua tubuh/ jasad yang sempurna dan ketiga adalah akal yang mampu membuat manusia bisa menaklukkan dunia dan alam sekitarnya untuk memudahkan kehidupannya. ${ }^{16}$

\section{Urgensi Akal Menurut Al Qur'an}

Perkembangan (development) adalah proses atau tahapan pertumbuhan ke arah yang lebih maju. Pertumbuhan sendiri (growth) berarti tahapan peningkatan sesuatu dalam hal jumlah, ukuran, dan arti pentingnya. Partumbuhan juga dapat berarti sebuah tahapan perkembangan a stage of development.

Dalam Dictionary of Psychology dan The Penguin Dictionary of Psychologhy, arti perkembangan pada prinsipnya adalah tahapan-tahapan perubahan yang progresif yang terjadi dalam rentang kehidupan manusia dan organisme lainnya, tanpa membedakan aspek-aspek yang terdapat dalam diri organisme-organisme tersebut.

Salah satu bentuk keunikan manusia adalah potensi-potensi yang berbeda antara manusia satu dengan manusia yang lain. Ada yang berpotensi besar dan ada pula yang berpotensi biasa saja. Hal ini dapat kita amati pada ayat-ayat suci berikut: "Perhatikanlah bagaimana Kami lebihkan sebagian dari mereka atas sebagian (yang lain). Dan pasti

16 Usman bin Hasan bin Ahmad asy Syakir (tth), Durrotun Nasihin; Bab Keutamaan manusia, (Semaranag: Pustaka 'Alawiyah, 1996), h, . 118

${ }^{17}$ Departemen Agama, Q.S. Al-Isra': 21 kehidupan akhirat lebih tinggi tingkatnya dan lebih besar keutamaannya."(Q.S. AlIsra': 21) ${ }^{17}$

Fakta-fakta tentang perbedaan potensial manusia ini antara lain dapat dicontohkan dalam hal kecerdasan intelektual maupun dalam spiritualitas. Hal ini menunjukkan bahwa dalam melaksanakan pengembangan diri seseorang memiliki kadarnya masingmasing sehingga tidak ada standar yang menjadi acuan perkembangan, pun begitu perkembangan masih tetap bisa dilihat dari komparasi potensi awal dengan perkembangan yang telah dicapai. ${ }^{18}$

Salah satu unsur terpenting bagi pengembangan diri manusia adalah akal. Akal merupakan alat untuk berpikir dan dia tidak bisa direalisasikan dalam bentuk konkritnya, akan tetapi secara abstrak akal berupa ideal yang utama dari diri manusia. Adanya akal telah mengangkat manusia lebih jauh sempurna dibandingkan dengan makhluk lain.

Menurut Emha Ainun Najib Akal merupakan kunci dari kemanusiaan. Akal adalah ketika otak mendapat sentuhan iradah dan ilmu Allah sehingga terjadilah proses berpikir. Peristiwa materiilnya mungkin berupa gelombang atau magnet dari Allah ke ubun-ubun kepala manusia. Akal adalah komposisi antara hardware dan software. ${ }^{19}$

18 Fuad Nashori, Potensi-Potensi Manusia, (Yogyakarta:Pustaka Pelajar) , h, . 92-94

${ }^{19}$ https://www.caknun.com/2014/reportas e-kenduri-cinta-januari-2014-ahmaq/dilihat pada 11-04-2018, pukul: 01.06. 
Pendapat al-Ghazali, bahwa akal salah satu dimensi terpenting pada diri manusia, dimana akal sebagai alat berpikir telah memberi andil besar terhadap alur kehidupan manusia, mempolakan hidup dan mengatur proses kehidupan secara esensial. Akal telah bekerja menurut ukuran yang ada, karenanya maka al-Ghazali membagi akal dalam beberapa daya. Klasifikasi tentang akal ini menurut al-Ghazali dilihat dari potensi dan kadar akal dalam beberapa macam, yaitu akal praktis dan akal teoritis. Akal praktis merupakan saluran yang menyampaikan gagasan-gagasan akal teoritis kepada daya penggerak (almuharrikat) sekaligus merangsangnya menjadi aktual. $^{20}$

$$
\text { Dalam perspektif Islam, }
$$
pendidikan memainkan peran penting dalam upaya melahirkan manusia yang handal dan dapat menjawab tantangan zaman. Sumber daya manusia merupakan gerakan human investment. ${ }^{21}$ Human Investment adalah upaya pendidikan jangka panjang untuk melahirkan sumber daya manusia yang optimal. Pengembangan sumber daya manusia bukan merupakan persoalan yang mudah karena membutuhkan pemikiran, langkah, aksi yang sistematik, sistemik, dan serius. Karena berusaha memberikan konstruksi yang utuh tentang manusia dengan mengem-

${ }^{20}$ M. Yasir Nasution (1996), Manusia Menurut Al-Ghazali, (Jakarta:Grafindo Persada,1996), h, . bangkan seluruh potensi dasar manusia dan bagaimana aktifitasnya.

Hakekat pengembangan sumber daya manusia dalam pendidikan Islam adalah usaha sadar agar sumber daya manusia atau potensi-potensi manusia tumbuh dan berkembang seoptimal mungkin sesuai dengan kapasitas tujuan pendidikan Islam. ${ }^{22}$

Potensi yang dimaksud mencakup berbagai macam potensi diantaranya:

1. Potensi akal; Manusia me-miliki potensi akal yang dapat menyusun konsep-konsep, mencipta, mengembangkan, dan mengemukakan gagasan. Dengan potensi ini manusia dapat melaksanakan tugas-tugasnya sebagai khalifah di muka bumi. Namun faktor subjektifitas manusia dapat mengarah pada kesalahan dan kebenaran

2. Potensi Ruh; Manusia tentu memiliki ruh. Sebagian para ahli mengatakan bahwa ruh adalah nyawa sementara sebagian yang lain memahami bahwa ruh pada manusia sebagai dukungan dan peneguhan kekuatan batin. Terlepas dari mana yang benar soal ruh ini memang bukan urusan manusia karena manusia hanya sedikit ilmu pengetahuan tentangnya.

3. Potensi Qalbu; Qalbu tidak dimaknai sekedar hati yang ada pada manusia. Qalbu lebih mengarah pada aktifitas

21 Yasmadi, Modernisasi Pesantren Kritik Nurcholis Madjid terhadap Pendidikan Islam Tradisional,, Jakarta: Ciputra Pres), h, . 152

22 Yunus Abu Bakar, Filsafat Pendidikan Islam, Ibid, 82 
rasa yang bolak-balik. Sesekali senang, sesekali susah, kadang setuju, kadang menolak dan sebagainya.

4. Potensi Fitrah; Manusia pada saat lahir memiliki potensi fitrah, fitrah bukan berarti sesuatu yang suci melainkan bawaan sejak lahir.

5. Potensi Nafs; Dalam bahasa Indonesia nafs diserap menjadi nafsu yang berarti dorongan yang kuat untuk berbuat kurang baik. Sementara nafs yang ada pada manusia tidak hanya dorongan berbuat buruk, tetapi juga berpotensi berbuat baik dengan kata lain berpotensi positif dan negatif. 23

Dari semua potensi yang ada, semuanya saling terkait dengan yang lain namun kita melihat ada sedikit keunggulan akal dalam mengembangkan potensi ini meskipun tidak terlalu berdampak terhadap kesemuanya namun paling tidak akal mampu mempengaruhi qalb, fitrah dan nafs dalam kehidupan sesuai perkembangan yang dicapai.

Sebagaimana telah diketahui sebelumnya bahwa sumber pengetahuan manusia terdiri dari rasio, pengalaman, intuisi, dan wahyu. Dengan keempat inilah manusia mencari apa yang disebut dengan kebenaran.

1. Rasio
Rasio biasa kita mengenalnya sebagai akal pikiran. Kata akal berasal dari kata Arab, yaitu al-'aql yang dalam bentuk kata benda tidak terdapat dalam Al-Qur'an. Al Qur'an hanya menyebutnya dalam bentuk kata kerja seperti'aqaluh, ta'qilun, na'qil, ya'qiluha dan ya'qilun yang mengandung arti faham dan mengerti.

Manusia yang menjadikan rasio atau akal sebagai sumber pengetahuan disebut dengan kaum rasionalis yang mengembangkan paham rasionalisme, yaitu paham yang menyatakan bahwa idea tentang kebenaran itu sudah ada dan pikiran manusia dapat mengetahui idea tersebut namun tidak menciptakannya dan tidak juga mempelajarinya lewat pengalaman (paham idealisme). Dengan perkataan lain, idea tentang kebenaran, yang menjadi dasar pengetahuan, diperoleh lewat berpikir rasional, terlepas dari pengalaman manusia. Sistem pengetahuan dibangun secara koheren di atas landasanlandasan pernyataan yang sudah pasti. ${ }^{24}$

\section{Pengalaman / Empiris}

Kebalikan dari kaum rasionalis, maka kaum empiris berpendapat bahwa pengetahuan manusia bersumber pada pengalaman yang kongkret. Gejalagejala alamiah merupakan sesuatu yang bersifat kongkret dan dapat dinyatakan lewat tangkapan pancaindera manusia. Melalui gejala-gejala atau kejadian-

\footnotetext{
23 Yasmadi, Modernisasi Pesantren, Ibid, h, . 152
}

24 JuJun S. Suriasumantri Ilmu Dalam Perspektif sebuah kumpulan karangan tentang hakekat ilmu, (Jakarta: Yayasan Obor Indonesia, 1997) h, 10 
kejadian yang berulang-ulang dan menunjukkan pola yang teratur, memungkinkan manusia untuk melakukan generalisasi. Dengan mempergunakan metode induktif maka dapat disusun pengetahuan yang berlaku secara umum lewat pengamatan terhadap gejala-gejala fisik yang bersifat individual.

Kaum empiris menganggap bahwa dunia fisik adalah nyata karena merupakan gejala yang dapat tertangkap oleh pancaindera, sedangka panca indera manusia sangat terbatas kemampuannya dan terlebih penting lagi bahwa pancaindera manusia bias melakukan kesalahan. Misalnya bagaimana mata kita melihat sebatang pensil yang dimasukkan ke dalam gelas bagian yang terendam air terlihat bengkok.

\section{Intuisi}

Intuisi merupakan pengetahuan yang didapatkan tanpa melalui proses penalaran tertentu. Seseorang yang sedang terpusat pikirannya pada sesuatu masalah tiba-tiba saja menemukan jawaban atas permasalahan tersebut. Tanpa melalui proses berpikir yang berliku-liku tiba-tiba saja dia sudah sampai situ. Jawaban permasalahan yang sedang dipikirkannya muncul dibenaknya bagaikan kebenaran yang membukakan pintu. ${ }^{25}$

\section{Wahyu}

Wahyu berasal dari kata Arab alwahy dan al-wahy adalah kata asli Arab dan bukan kata pinjaman dari bahasa asing. Kata itu berarti suara, api dan kecepatan. Disamping itu ia juga mengandung arti bisikan, isyarat, tulisan dan kitab. Al-Wahy selanjutnya mengandung pengertian pemberitahuan secara tersembunyi dan dengan cepat. Yang dimaksud dengan wahyu sebagai sumber pengetahuan adalah wahyu yang diturunkan kepada orang pilihan-Nya agar diteruskan kepada umat manusia agar dijadikan pegangan hidup berisi ajaran, petunjuk dan pedoman yang diperlukan bagi umat manusia di dunia dan akhirat. Dalam Islam wahyu yang disampaikan kepada Nabi Muhammad SAW terkumpul dalam Al-Qur'an. ${ }^{26}$

Dari ke empat sumber pengetahuan manusia, yang ada di atas dapat kita lihat bahwa kesemuanya menggunakan kinerja akal dari manusia. Misal: rasio, dalam rasio seseorang membutuhkan akal untuk berpikir dan membuat sintesa, lalu pengalaman, hal ini juga memerlukan kerja akal untuk melakukan kesimpulan dari apa yang dia alami, selanjutnya intuisi, dalam hal ini akal akan menimbang pilihan-pilihan yang ada dalam intuisi untuk memilih hal yang dikerjakan, lalu wahyu, tidak mungkin seseorang memahami wahyu tanpa menggunakan akal karena akal sendiri disini berfungsi sebagai penerjemah dan alat memahami. Inilah mengapa kemudian akal sangatlah penting dalam pengembangan diri manusia. untuk

${ }^{26}$ Harun Nasution, Akal dan Wahyu dalam Islam, (Jakarta: Bumi Aksara, 1994), h, 15 
mendapatkan ilmu seseorang harus faham dan mengerti sesuatu itu, dan untuk mengerti dan memahami maka disinilah fungsi akal manusia. Sehingga perkembangan diri manusia tak akan pernah tercapai tanpa penggunaan akal. Sehingga urgensi akal dalam pengembangan diri manusia memegang peranan yang penting dan mendasar.

\section{Implikasi Akal dalam Mencapai Tujuan Pendidikan Islam}

Berbicara mengenai implikasi, bahwa implikasi memiliki makna keterlibatan atau keadaan terlibat. Keadaan terlibat secara tidak langsung juga akan menunjukkan sebagai kata lain peran. Maka dari makna ini dapat kita fahami pembahasan pada bab ini adalah terkait dari keterlibatan akal dalam mencapai tujuan pendidikan.

Sebelum membahas terkait implikasi akal terlebih dahulu kita fahami tentang Tujuan pendidikan Islam. Pendidikan Islam berarti pembentukan pribadi muslim. Isi pribadi muslim itu adalah pengamalan sepenuhnya ajaran Allah dan RasulNya. Tetapi pribadi muslim itu tidak akan tercapai atau terbina kecuali dengan pengajaran dan pendidikan. Membina pribadi muslim adalah wajib.

Dan karena pribadi muslim tidak mungkin terwujud kecuali dengan pendidikan, maka pendidikan itupun menjadi wajib dalam pandangan Islam.

Dalam ajaran Islam bertakwa itu wajib, tetapi tidak mungkin bertakwa itu tercapai kecuali dengan pendidikan, maka pendidikan itu juga wajib. Dan manusia adalah makhluk pedagogik yang mana untuk memahami atau melakukan sesuatu ia harus belajar, maka kewajiban menyelenggarakan pendidikan adalah kewajiban syar'i yang berarti pula bahwa perintah bertakwa adalah sekaligus perintah menyelenggarakan pendidikan yang menuju kepada pembinaan manusia takwa.

Islam adalah "konsep" pemasrahan diri kepada Allah, agar kita selamat (salam) di dunia dan akhirat. Untuk sampai tataran ini, Allah sudah member bekal kepada makhlukNya bernama manusia tiga hal, yakni akal, hati, dan syahwat. Akal atau intelektual adalah kata kunci untuk terus mencari Islam, karena ini sebuah kata kerja, dan syahwat sesungguhnya adalah "ghirah" atau semangat (bisa positif, bisa negatif, tergantung kualitas akal spiritual kita). Makanya Allah memerintahkan kita untuk meng-empan papan-kan, memproporsional-kan ketiga hal tersebut.

Dalam memahami tujuan pendidikan Islam tidak dapat terlepas dari tujuan manusia diciptakan, yakni sebagai hamba Allah dan khalifah. Dalam dinamikanya khalifatullah adalah tataran tertinggi, setelah manusia mampu melewati tataran lain sebagai insan (manusia), abdullah (abdi Allah). Kalau manusia baru berada dalam tataran manusia (insan), maka yang muncul dalam dirinya adalah masih ego pribadi, dan belum menganggap yang lainnya juga bagian dari alam semesta yang harus bersujud kepada Tuhan. Selanjutnya jika ia sudah 
sampai kepada pemahaman bahwa dirinya dan yang lainnya adalah bagian dari alam semesta yang harus sujud dan mengabdi kepada Allah, maka ia sudah sampai pada tataran Abdullah. Tataran ini belum sampai pada kesadaran memikul tugas memanajemen bumi dan isinya. Barulah jika ia sudah mampu menggunakan akal untuk "memayu hayuning bawana", atau memanajemen bumi, maka ia sudah sampai pada tataran khalifatullah. ${ }^{27}$

Pendidikan Islam bersifat elastis dan selalu mengedepankan akal manusia. Pintunya terbuka lebar-lebar bagi setiap orang yang ingin belajar dan sanggup untuk memahami pengetahuan, mendorong seseorang untuk terus menerus belajar dan melakukan penyelidikan (pemeliharaan), tanpa melihat batas umur. ${ }^{28}$ Karena tujuan utama pendidikan Islam adalah membentuk moral dan akhlak yang tinggi serta melakukan yang mulia.

Sebagaimana telah dijelaskan di bab sebelumnya bahwa pendidikan Islam memiliki tujuan untuk menjadikan manusia sebagai insan kamil, yang dimaksud insan kamil adalah manusia yang secara pengetahuan ia mampu menjalankan agama islam sebagai ilmu, yang mana islam menjadi nafas dari segala perilakunya di dunia.

Ciri-ciri insan kamil dapat di telusuri dari berbagai pendapat yang

27 https://www.caknun.com/2015/islam- dikemukakan oleh para ulama yang keilmuannya sudah diakui yang termasuk didalamnya aliran-aliran, ciri tersebut sebagai berikut:

1. Berfungsi Akalnya Secara Optimal

Fungsi akal secara optimal dapat dijumpai pada pendapat kaum muktazilah. Menurutnya manusia yang akalnnya berfungsi secara optimal dapat mengetahui bahwa segala perbuatan baik seperti adil, jujur, berakhlak sesuai esensinya dan merasa wajib melakukan semua itu walaupun tidak diperintahkan oleh wahyu. Manusia yang berfungsi akalnya sudah merasa wajib melakukan perbuatan yang baik. Dan manusia yang demikian yang dapat mendekati tingkat insan kamil. Dengan demikian bahwa insane kamil adalah orang yang akalnya dapat mengenali perbuatan yang baik dan perbuatan yang buruk.

2. Mampu Meciptakan Budaya

Sebagai bentuk pengamalan dari berbagai potensi yang terdapat pada dirinya sebagai insan, manusia yang sempurna adalah manusia yang mampu mendayagunakan seluruh potensi rohaniahnya secara optimal. Menurut ibn Khaldun manusia adalah makhluk berpikir.

3. Berjiwa Seimbang

Perlunya seimbang dalam kehidupan, yaitu seimbang antara pemenuhan kebutuhan material dengan spiritual atau ruhiyah. Ini berarti perlunya ditanamkan jiwa sufistik yang

\footnotetext{
28 Muhammad Athiyah al-Abrasy, Prinsipprinsip Dasar Pendidikan Islam, terj. AlTarbawiyah al-Islamiyah, (Bandung: Pustaka Setia, 2003), h, . 32
} 
dibarengi dengan pengamalan syariat Islam, terutama ibadah, zikir, tafakkur, muhasabbah, dan seterusnya. Karena dengan jiwa yang seimbang manusia lebih memiliki peluang untuk menjadi lebih baik.

Uraian di atas diyakini belum menjelaskan ciri-ciri insan kamil secara keseluruhan. Tetapi ciri-ciri itu saja jika diamalkan secara konsisten dipastikan akan mewujudkan insan kamil yang dimaksud. Seluruh ciri tersebut menunjukkan bahwa insan kamil lebih menunjukkan pada manusia yang segenap potensi intelektual, intuisi, rohani, hati sanubari, ketuhanan, fitrah dan kejiwaannya berfungsi dengan baik. Jika demikian halnya, maka upaya mewujudkan insan kamil perlu diarahkan melalui pembinaan intelektual, kepribadian, akhlak, ibadah, pengamalan tasawuf, bermasyarakat, research. ${ }^{29}$

Maka dari itu pendidikan sebagai proses harus mengakomodasi seluruh kepentingan tujuan pendidikan yang telah tertulis di atas. Karena proses haruslah sesuai dengan tujuan yang akan dicapai. Sebagaimana disebutkan Al-Aynayni tujuan pendidikan islam memiliki dua dimensi yakni tujuan umum dan tujuan khusus. Tujuan umum adalah beribadah kepada Allah, maksudnya membentuk manusia yang beribadah beribadah kepada Allah. Tujuan umum ini sifatnya tetap, berlaku di segala tempat, waktu, dan keadaan.
Tujuan khusus pendidikan islam ditetapkan berdasarkan keadaan tempat dengan mempertimbangkan keadaan geografi, ekonomi, dan lain-lain yang ada di tempat itu. Tujuan khusus ini dapat dirumuskan berdasarkan ijtihad para ahli di tempat itu. ${ }^{30}$

Dalam kaitannya mencapai tujuan pendidikan Islam, sebagai makhluk berakal, manusia mengamati sesuatu. Hasil dari pengamatan itu diolah sehingga menjadi ilmu pengetahuan. Dengan ilmu pengetahuan itu dirumuskannya ilmu baru yang akan digunakannya dalam usaha memenuhi kebutuhan hidupnya dan menjangkau jauh di luar kemampuan fisiknya. demikian banyak hasil kemajuan ilmu pengetahuan yang membuat manusia dapat hidup menguasai alam. ${ }^{31}$

Dengan menggunakan akalnya untuk berfikir, merenung, serta menghayati, manusia akan mampu mengembangkan gagasan, konsep dan ide-ide cemerlang, sehingga tujuan dari pendidikan Islam akan tercapai yaitu untuk menumbuhkan dan meningkatkan keimanan melalui pemberian dan pemupukan pengetahuan, penghayatan, pengamalan, serta pengalaman seseorang tentang agama Islam sehingga menjadi manusia muslim yang terus berkembang dalam hal keimanan, 
ketakwaannya, berbangsa dan bernegara. ${ }^{32}$

Kemudian pemahaman terhadap potensi berpikir yang dimiliki akal sebagaimana yang telah dipaparkan di atas memiliki hubungan yang amat erat dengan pendidikan. Hubungan tersebut antara lain terlihat dalam merumuskan tujuan pendidikan. Benyamin Bloom, Cs, dalam bukunya Taxonomy of Educational Objective (1956) yang dikutip oleh Nasution, membagi tujuantujuan pendidikan dalam tiga ranah (domain), yaitu ranah kognitif, afektif dan psikomotorik. Tiap-tiap ranah dapat dirinci lagi dalam tujuan-tujuan yang lebih spesifik yang hierarkis. Ranah kognitif dan afektif tersebut sangat erat kaitannya dengan fungsi kerja dari akal. Dalam ranah kognitif terkandung fungsi mengetahui, memahami, menerapkan, menganalisis, mensintesis dan mengevaluasi. ${ }^{33}$

Implikasi akal dalam mencapai tujuan pendidikan islam dari uraian diatas dapat kita fahami bahwa akal sebagai alat utama bagi manusia untuk mendapatkan ilmu, dan untuk berilmu seseorang harus melalui pendidikan sebagai proses, dengan ilmu pula seseorang akan mengalami perkembangan dalam dirinya, selanjutnya setelah ia berkembang seseorang akan mampu menjadi insan kamil yang memiliki dimensi keduniaan dan akhirat, dengan keseimbangan antara hubungan dengan Tuhan, hubungan dengan sesame manusia dan hubungan dengan alam. Dengan demikian Akal sangat berimplikasi dalam menentukan antara tercapai atau tidaknya tujuan pendidikian Islam, mengingat bahwa akal dalam hubungannya dengan manusia adalah bagian yang harus ada dan tak terpisahkan, karena manusia disebut sebagai manusia tidak lain karena kepemilikan akalnya yang juga merupakan pembeda antara manusia dengan makhluk yang lain.

\section{Kesimpulan}

Dari pembahasan hasil penelitian yang telah penulis paparkan dalam artikel tentang urgensi akal dan implikasinya dalam mencapai tujuan pendidikan Islam (studi integratif Islam dan filsafat), dapat diambil kesimpulan sebagai berikut:

1. Akal diartikan sebagai daya berfikir yang ada dalam diri manusia akal juga mengandung arti berfikir, memahami dan mengerti. Akal merupakan suatu potensi ruhaniah yang

2. Implikasi akal dalam mencapai tujuan pendidikan Islam dan pemahaman terhadap pengetahuanpengetahuan tentang segla kelilmuan yang diturunkan oleh Allah SWT.
32 Abdul Majid dan Dian Andayani, Pendidikan Agama Islam Berbasis Kompetensi, B(andung: PT Remaja Rosdakarya, 2004), h, . 135 


\section{Daftar Pustaka}

Andayani A.M.D (ed.) (2004), Pendidikan Agama Islam Berbasis Kompetensi, PT Remaja Rosdakarya, Bandung

Nata.A (2002), Tafsir Ayat-ayat Pendidikan, PT. Raja Grafindo Persada, Jakarta.

-(2015), Akhlak Tasawuf Dan Karakter Mulia, Raja Grafindo Persada, Jakarta.

Cholik, A.A (2015), Relasi Akal dan Hati menurut Al-Ghazali, Jurnal Vol. 13, No. 2, UNIDA Gontor, Ponorogo.

Ibrahim, A.S. (2012), Misteri Potensi Ghaib Manusia, Qisthi Press, Jakarta.

Tafsir. A. (2013), Ilmu Pendidikan Islam, Remaja Rosdakarya, Bandung

Baharuddin (2009), Pendidikan dan Psikologi Perkembangan, Ar-Ruzz Media, Yogyakarta.

Salam B. (1988), Filsafat Manusia, Antropologi Metafisika, Bina Aksara, Jakarta.

Papalia D.E. (2008), Human Development (Psikologi Perkembangan), Kencana, Jakarta.

Anshori E.S. (1982), Ilmu Filsafat dan Agama, Bina Ilmu, Surabaya.

Nashori F. (2003), Potensi-Potensi Manusia, Pustaka Pelajar, Yogyakarta.

Fuadi (2013), Peran Akal Menurut Pandangan Al-Ghazali, Jurnal Substantia Vol. 15, No. 1, IAIN Ar-Raniry, Banda Aceh.
Harun Nasution (1994), Azas-azas Kurikulum, Bumi Aksara, Jakarta.

Hasan Langgulung (2004), Manusia dan Pendidikan; Suatu Analisa Psikologis, Fisafat dan Pendidikan, Pustaka Al Husna Baru, Jakarta.

Jalaluddin (2017), Filsafat Pendidikan Islam Dari Zaman Ke Zaman, Rajawali Pers, Jakarta.

JuJun S. Suriasumantri (1997), Ilmu Dalam Perspektif sebuah kumpulan karangan tentang hakekat ilmu, Yayasan Obor Indonesia, Jakarta.

Khafidhi (2013), Peranan Akal dan Qalb Dalam Pendidikan Akhlaq (Studi Pemikiran Al-Ghazali), IAIN Walisongo, Semarang.

M. Ngalim Purwanto (2002), Psikologi Pendidikan, PT Remaja Rosdakarya, Bandung, hlm. 85

M. Yasir Nasution (1996), Manusia Menurut Al-Ghazali, Grafindo Persada, Jakarta.

M.A. Santoso Fattah, dkk (2013), Studi Islam 3, (LPIK) Universitas Muhammadiyah Surakarta, Surakarta.

Maftuh Ahnan \& Ach. Zacky Syafa (2001), Filsafat Manusia, Terbit Terang, Surabaya

Moch. Syarif Hidayatullah (2010), Karunia Akal yang Disia-siakan, Penerbit Erlangga, Jakarta.

Muhammad Athiyah al-Abrasyi (2003), Prinsip-prinsip Dasar Pendidikan Islam, terj. Al-Tarbawiyah alIslamiyah, Pustaka Setia, Bandung, 
Muhammad Husain Abdullah (2003), Mafahim Islamiyah, terjemah, alIzzah, Bangil.

Muhammad Izzudin Taufiq (2006), Panduan Lengkap dan Praktis Psikologi Islam, Gema Insani Press, Jakarta.

Musa Asy'arie (1992), Manusia pembentuk Kebudayaan Dalam alQur'an, Lembaga Studi Filsafah Islam, Yogyakarta.

Yasmadi (2002), Modernisasi Pesantren Kritik Nurcholis Madjid terhadap Pendidikan Islam Tradisional, Ciputat Press, Jakarta

Yusuf Qardhawi (1996), Al Qur'an Berbicara tentang Akal dan Ilmu Pengetahuan, Gema Insani, Jakarta.

Zuhairini (2012), Filsafat Pendidikan Islam, Bumi Aksara, Jakarta. 